\title{
Precalving and early lactation factors that predict milk casein and fertility in the transition dairy cow
}

\author{
Rachael M. Rodney, ${ }^{*}{ }^{1}$ Jenianne K. Hall, $\ddagger$ Charlotte T. Westwood,§ Pietro Celi,\#ll and lan J. Lean ${ }^{*} \dagger$ \\ *Scibus, Camden, New South Wales, Australia 2570 \\ †Faculty of Veterinary Science, The University of Sydney, Camden, New South Wales, Australia 2570 \\ $\ddagger$ Halltech Services, Orange, New South Wales, Australia 2800 \\ §Kimihia Research Centre, PGG Wrightson Seeds Limited, Lincoln, Canterbury, New Zealand 7640 \\ \#Animal Nutrition and Health, DSM Nutritional Products, Columbia, MD 21045 \\ IIFaculty of Veterinary and Agricultural Sciences, The University of Melbourne, Parkville, Victoria, Australia, 3010
}

\begin{abstract}
Multiparous Holstein cows $(\mathrm{n}=82)$ of either high or low genetic merit (GM) (for milk fat + protein yield) were allocated to 1 of 2 diets in a $2 \times 2$ factorial design. Diets differed in the ratio of rumen-undegradable protein (RUP) to rumen-degradable protein (37\% RUP vs. $15 \%$ RUP) and were fed from $21 \mathrm{~d}$ precalving to 150 days in milk. This study evaluated the effects of these diets and GM on concentrations of milk casein $(\mathrm{CN})$ variants and aimed to identify precalving and early lactation variables that predict milk $\mathrm{CN}$ and protein yield and composition and fertility of dairy cows. It explored the hypothesis that low milk protein content is associated with lower fertility and extended this hypothesis to also evaluate the association of $\mathrm{CN}$ contents with fertility. Yields $(\mathrm{kg} / \mathrm{d})$ for $\mathrm{CN}$ variants were 0.49 and 0.45 of $\alpha-\mathrm{CN}, 0.38$ and 0.34 of $\beta-\mathrm{CN}, 0.07$ and 0.06 for $\kappa-\mathrm{CN}$, and 0.10 and 0.09 of $\gamma-\mathrm{CN}$ for high- and lowRUP diets, respectively. Increased RUP increased milk, $\mathrm{CN}$, and milk protein yields. Increased GM increased milk protein and $\gamma$-CN yields and tended to increase milk CN yield. The effects of indicator variables on $\mathrm{CN}$ variant yields and concentrations were largely consistent, with higher body weight and $\alpha$-amino nitrogen resulting in higher yields, but lower concentrations. An increase in cholesterol was associated with decreased $\mathrm{CN}$ variant concentrations, and disease lowered CN variant yield. A diet high in RUP increased proportion of first services that resulted in pregnancy from 41 to $58 \%$. Increased precalving metabolizable protein (MP) balance decreased the proportion of first services that resulted in pregnancy when evaluated in a model containing CN percentage, milk protein yield, diet, and
\end{abstract}

Received August 18, 2015.

Accepted April 14, 2016.

${ }^{1}$ Corresponding author: rachaelr@scibus.com.au
GM. This finding suggests that the positive effects of increasing dietary RUP on fertility may be curvilinear because cows with a very positive MP balance before calving were less fertile than those with a lower, but positive, MP balance. Prepartum MP balance was important to production and reproductive outcomes, but surprisingly, metabolizable energy balance was not. The hazard of pregnancy in the first $150 \mathrm{~d}$ of lactation was $28 \%$ lower in cows producing milk with the lowest quartile of protein percentage compared with cows with milk in the upper 3 quartiles. Milk CN percentage was positively associated with improved pregnancy at first service. This study demonstrates the importance of protein metabolism to reproductive performance of the dairy cow.

Key words: fertility, protein degradability, casein

\section{INTRODUCTION}

Good nutritional management of dairy cattle during the transition period can improve their responses to the metabolic challenges posed by late pregnancy and early lactation (Bell, 1995; Lean et al., 2014). Hence, metabolic status and dietary interventions before calving are valuable to study as predictors of future productivity and reproductive performance (Bell, 1995). Much of the research in this area has focused on nutritional interventions after calving or around the time of conception (Patton et al., 2007), but these metabolic processes can be influenced before calving and in early lactation because the body tissue reserves the cow has available affect subsequent productivity and health (LeBlanc, 2010; Lean et al., 2013; Bradford et al., 2015). Identifying the key indicators associated with better productive and reproductive outcomes may allow cattle to be better fed and managed to achieve maximum productivity. Evidence exists that higher producing cows have lower fertility (Spalding et al., 
1975; Lean et al., 1989) and that genetic selection for increased production can reduce fertility (Hageman et al., 1991; Buckley et al., 2000; Horan et al., 2005; Pollott and Coffey, 2008). These observations suggest the need to investigate differences in productive and reproductive performance and metabolism in cows of differing genetic merit (GM).

Bovine milk contains 2.5 to $3.5 \%$ true protein, approximately $80 \%$ of which is CN (Coulon et al., 1998). Casein has 4 main variants $\left(\alpha_{\mathrm{S}^{-}} \mathrm{CN}, \alpha_{\mathrm{S}^{2}} \mathrm{CN}, \beta-\mathrm{CN}\right.$, and $\kappa-\mathrm{CN}$ ) and an additional class, $\gamma-\mathrm{CN}$, which is a product of postsecretion proteolytic breakdown of $\beta$-CN (Fox and Mulvihill, 1982). Each CN variant may have distinct properties, but it is not known if different $\mathrm{CN}$ variants are associated with better production or reproductive outcomes, or what factors affect production of specific variants. It is well recognized that increased dietary RUP and metabolizable AA flux can increase milk yield when fed during early lactation (Carroll et al., 1994; Cunningham et al., 1996; McCormick et al., 1999; Doepel et al., 2004), but knowledge of the effects of protein nutrition during the precalving period is more limited, and 2 meta-analyses failed to identify optimal estimated MP (Lean et al., 2003) or dietary CP concentrations (Lean et al., 2012). The role of specific AA nutrition precalving on production and reproductive performance remains to be determined, but nutritional principles dictate that AA nutrition must be important.

Cattle can use nutrients from the diet and from endogenous body reserves, hence diet is important both before calving, when body reserves are being accreted, and during lactation and the breeding period. Dietary protein intake is of particular interest because improved protein nutrition in transition and early lactation can improve production, fertility, and health in the dairy cow (van Saun et al., 1993). Milk yield was unchanged when RUP concentration in the diet was increased before calving (van Saun et al., 1993), but milk protein percentage increased from 2.96 to $3.18 \%$. Increasing the amount or degradability of dietary protein lowers the proportion of cows pregnant to service (Butler, 2000; Lean et al., 2012); however, decreasing the degradability of the dietary protein can improve reproductive outcomes (Folman et al., 1981; Carroll et al., 1994). Further, large observational studies suggest that reproductive performance is improved in cows with high milk protein concentration (Moss, 2001; Buckley et al., 2003; Morton, 2004; Madouasse et al., 2010). Given that $\mathrm{CN}$ represents $80 \%$ of milk proteins, it can be hypothesized that evaluating the precalving factors that influence $\mathrm{CN}$ variants and milk protein concentration may provide insight into the metabolic pathways that are associated with both lower milk protein and lower fertility. Further, the effects of GM on CN, milk, milk protein production and content, and fertility should be examined in the context of these studies. Given that very few detailed studies of milk $\mathrm{CN}$ variants exist and none of these provide reproductive data, this study provides a unique opportunity to examine relationships between these factors and diet, GM, and metabolic status as reflected by precalving indicators and immediate postcalving measures, albeit with limited numbers of cattle.

The indicator variables that most reliably predict future reproductive and productive performance are yet to be defined. Body weight and BCS are often used as easily measured proxies for energy or, more critically, nutrient reserves (Edmondson et al., 1989), and excessive loss or low levels of these nutrients are associated with lower fertility (Garnsworthy and Topps, 1982; Buckley et al., 2003; López-Gatius et al., 2003). Similarly, changes in or absolute values for blood metabolites, including glucose, free fatty acids, BHB, insulin, and IGF-I, have been associated with changes in reproductive performance (Leroy et al., 2005, 2008; LeBlanc, 2010; Ospina et al., 2010; Chapinal et al., 2012); however, these indicators are not uniformly associated with adverse reproductive outcomes (Chapinal et al., 2012). The importance of metabolic factors during lactation that influence fertility was examined by Westwood (1998) and Westwood et al. (2000, 2002), but metabolite concentrations during the period before calving have not been as comprehensively evaluated as indicators of future performance. As such, one goal of this study was to screen factors during the prepartum period as potential indicators of future productive and reproductive performance.

In the current study, we reanalyzed data from an older study (Garvin, 1999; Westwood et al., 2000, 2002) and modeled some new data to (1) describe the effects of protein nutrition and GM on CN variants; (2) to explore precalving and early lactation factors that may predict production, especially protein and CN production, and reproductive performance; (3) to evaluate an a priori hypothesis that low milk protein content is associated with poor fertility and to understand the factors, including $\mathrm{CN}$ variant yield and composition, that contribute to this situation.

\section{MATERIALS AND METHODS}

\section{Cows and Feeding}

This study is a re-examination and extension of data obtained from studies by Garvin (1999) and Westwood et al. (2000, 2002). Multiparous Holstein-Friesian cows 
( $\mathrm{n}=82$ ) were blocked by GM (high or low Australian Breeding Value $[\mathbf{A B V}]$ of milk fat + milk protein yield) and maintained on 1 of 2 diets differing in protein degradability from $21 \mathrm{~d}$ precalving to $150 \mathrm{~d}$ postpartum in a $2 \times 2$ factorial arrangement. Within GM groups, cows were paired according to calving date, age, and lactation number before random allocation to dietary group. Diets were isonitrogenous (dry cow $10.5 \% \mathrm{CP}$; lactating cow $19.3 \% \mathrm{CP}$ ) and isoenergetic (dry cow $10.0 \mathrm{MJ} / \mathrm{kg}$ of ME; lactating cow $11.3 \mathrm{MJ} / \mathrm{kg}$ of $\mathrm{ME}$ ) and differed in the ratio of RUP to RDP protein (37\% RUP:63\% RDP vs. $15 \%$ RUP: $85 \%$ RDP). Nineteen cows of high GM and 21 cows of low GM received the diet high in RUP, and 21 cows in each of the high and low genetic groups received the diet low in RUP. Cows were housed in an outdoor, shaded corral with a dirt floor, and feed was individually delivered, removed, and measured in a TMR via a Calan feeding system (American Calan Inc., Northwood, NH) located under shade and on a concrete base that was scraped daily. Before entry into the experiment cows were trained in use of this system. Total mixed rations consisted of chaffed alfalfa and oaten hays and a concentrate pellet. Full details of feed composition and analysis are available in Westwood et al. (2000) and in Supplementary Table S1 (http:// dx.doi.org/10.3168/jds.2015-10275).

\section{Data Collection}

Daily DMI was calculated individually for each cow and averaged weekly. Weekly BW and BCS (1-5 scale;
Edmondson et al., 1989) were recorded every $7 \pm 3.5 \mathrm{~d}$ from entry into trial until week 10 of lactation.

\section{Sample Collection and Analysis}

Coccygeal blood samples were collected weekly, commencing 3 wk before parturition until week 10 of lactation $(n=14 /$ cow $)$. Samples were analyzed for plasma BHB, cholesterol, glucose, urea, $\alpha$-amino nitrogen (AAN), and serum free fatty acid concentrations as described in Westwood et al. (2000).

Cows were milked twice daily, with milk yields recorded manually at each milking and an average daily production calculated weekly for the first $10 \mathrm{wk}$ of lactation. Milk fat and protein concentrations were determined weekly for the first 10 wk of lactation using infrared spectrometry (Milkoscan 605 analyzer, Foss Electric, Hillerød, Denmark). Skim milk was retained for $\mathrm{CN}$ precipitation and analysis at week 1 to 10 of lactation for casein yield and percentage, and weeks 2, 6 , and 10 of lactation for $\mathrm{CN}$ variant yields and percentages. This was multiplied by the amount of skim milk as a percentage of whole milk to obtain the $\mathrm{CN}$ concentration in whole milk $(\mathrm{mg} / \mathrm{mL})$. Individual $\mathrm{CN}$ variant yields were determined by fast protein liquid chromatography, using SDS-PAGE. The method used was described by Davies and Law (1987) with minor modifications as described by Garvin (1999). $\alpha$-Casein concentration was a combination of both $\alpha_{\mathrm{S}_{1}}-\mathrm{CN}$ and $\alpha_{S_{2}-}$ CN. For this study, average concentrations of blood metabolites and estimated ME and MP balance taken

Table 1. Description of variables included in models

\begin{tabular}{|c|c|c|}
\hline Variable $^{1}$ & Description $^{2}$ & Unit \\
\hline $\mathrm{AAN}$ & Plasma AAN, average for wk -3 to -1 & $\mathrm{mmol} / \mathrm{L}$ \\
\hline Genetic merit & Australian Breeding Value (ABV) for milk fat + protein yield & \\
\hline BW & Body live weight, average of wk -3 to -1 & $\mathrm{~kg}$ \\
\hline BCS & BCS, average for wk -3 to -1 & 1-5 scale, assessed to quarter points \\
\hline Calcium & Plasma calcium, average for wk -3 to -1 & $\mathrm{mmol} / \mathrm{L}$ \\
\hline Cholesterol & Plasma cholesterol, average for wk -3 to -1 & $\mathrm{mmol} / \mathrm{L}$ \\
\hline $\mathrm{BHB}$ & Plasma BHB, average for wk -3 to -1 & $\mathrm{mmol} / \mathrm{L}$ \\
\hline Glucose & Plasma glucose, average for wk -3 to -1 & $\mathrm{mmol} / \mathrm{L}$ \\
\hline ME balance & ME balance, average for wk -3 to -1 & MJ of $\mathrm{ME} / \mathrm{d}$ \\
\hline MP balance & MP balance, average for wk -3 to -1 & $\mathrm{~g} / \mathrm{d}$ \\
\hline Milk yield & Unless otherwise stated, average for milk yield for wk 1-3 of lactation & $\mathrm{kg} / \mathrm{d}$ \\
\hline Milk protein yield & Milk protein yield, average for wk $1-3$ of lactation & $\mathrm{kg} / \mathrm{d}$ \\
\hline Milk protein percentage & Milk protein percentage, average for wk $1-3$ of lactation & $\%$ whole milk \\
\hline Milk CN yield & Milk CN yield, average for wk $1-3$ of lactation & $\mathrm{kg} / \mathrm{d}$ \\
\hline Milk CN percentage & Milk CN percentage, average for wk $1-3$ of lactation & $\%$ whole milk \\
\hline $\mathrm{CN}$ variant yield & Milk $\alpha-, \beta-, \gamma-$, or $\kappa$-CN yield, average for wk 2,7 , and 10 of lactation & $\mathrm{kg} / \mathrm{d}$ \\
\hline $\mathrm{CN}$ variant percentage & $\begin{array}{l}\text { Milk } \alpha-, \beta-, \gamma-\text {, or } \kappa \text {-CN percentage, average for wk } 2,7 \text {, and } 10 \text { of } \\
\text { lactation }\end{array}$ & $\%$ whole milk \\
\hline Free fatty acids & Serum free fatty acids, average for wk -3 to -1 & $\mu \mathrm{mol} / \mathrm{L}$ \\
\hline Urea & Plasma urea, average for wk -3 to -1 & $\mathrm{mmol} / \mathrm{L}$ \\
\hline
\end{tabular}

${ }^{1} \mathrm{AAN}=\alpha$-amino nitrogen.

${ }^{2}$ Week in relation to parturition. 
in the 3 wk before calving and milk yield and composition in the first $3 \mathrm{wk}$ after calving were evaluated as indicator variables for inclusion in statistical models evaluating production and reproduction (Table 1).

\section{Reproduction}

Commencing $21 \pm 3.5 \mathrm{~d}$ after calving, all cows were monitored by rectal palpation of the reproductive tract to identify any condition that might compromise reproductive performance. The monitoring was repeated every 3 wk for cows that had not been inseminated during the previous $42 \mathrm{~d}$. A voluntary waiting period of $45 \mathrm{~d}$ was observed after which cows were bred 6 to $18 \mathrm{~h}$ after the observation of primary or secondary heat signs. Estrus detection, starting immediately after calving, was aided by visual observation for at least $14 \mathrm{~h} / \mathrm{d}$ and by placing KaMaR Heatmount detectors (Steamboat Springs, CO) on the tail-head of each cow. Cows were paired (one from each dietary group) and artificially inseminated with semen from the same ejaculate. All cows were inseminated by the same technician. Successful pregnancy was identified by a positive pregnancy test via palpation $42 \mathrm{~d}$ after a mating had occurred. Palpation was repeated $7 \mathrm{~d}$ later to confirm pregnancy, and once a pregnancy was confirmed, routine palpation was not continued. The interval from calving to pregnancy was defined as the number of days between calving and mating that resulted in a positive pregnancy test by palpation $42 \mathrm{~d}$ after mating. Full details of reproductive management and measurement are available in Westwood et al. (2000).

\section{Disease}

Treatment records were used to identify incidence of disease. Cows were classified as either being affected or not affected by "severe disease" between $6 \mathrm{wk}$ precalving to 150 DIM. Severe disease was classified as one or more of the following conditions being present: acute mastitis, retained fetal membrane or retained placenta, metritis or peritonitis, hypocalcaemia, ketosis, or displaced abomasum. The workers coding the diseases were not aware of the cows' production or reproductive outcomes.

\section{Nitrogen and Energy Balance Modeling}

Weekly MP balance was estimated for each cow from 3 wk prepartum until wk 10 of lactation using CPM dairy (version 3.08; Cornell-Penn-Miner, https://cahpwww. vet.upenn.edu/doku.php/software:cpm:purchase).

Calculations were based on dry cow rations in wk -3 to 0 (weeks numbered in relation to parturition at wk
0 ), early lactation rations in estimates for wk 1 , and lactation ration for wk 2 to 10 inclusive. Calculations included individual weekly DMI, BW, BCS, milk yield, milk fat percentage, milk protein percentage, parity, lactation status, age, and days pregnant. Dietary evaluations were based on the feed analysis results for the individual components of the diet. Feed evaluations were conducted on change of pellet or forage. Weekly ME balances were calculated based on formulas described by Agricultural and Food Research Council (AFRC, 1993) as detailed by Westwood et al. (2000).

\section{Statistical Analysis}

All data analysis was performed using Stata (Intercooled Stata v. 13, StataCorp, College Station, TX).

Production Variables. Descriptive analysis of variables was undertaken, and the effects of diet and GM for each variable are provided in Table 2. Diet and GM were included in all models as categorical variables. Mixed models (XTMIXED, Stata version 13.1) were used to explore the significance of the precalving indicator variables on milk yield and milk protein and CN yield and composition. Precalving indicator variables refer to serum free fatty acids, plasma AAN, calcium, cholesterol, BHB, glucose, and urea, ME balance, MP balance, BW, BCS, and the severe disease variable (Table 1). Effects of season had been evaluated previously and were found to be insignificant (Westwood et al., 2002). For all factors other than disease, an average value for the $3 \mathrm{wk}$ before calving was used. The following linear mixed model was used:

$$
Y_{i j k l}=\mu+\beta_{i}+\gamma_{j}+\theta_{k}+(\beta \gamma)_{i j}+(\beta \gamma \theta)_{i j k}+X_{l}+\varepsilon_{i j k l},
$$

where $Y_{i j k l}=$ response to diet $i(i=$ high RUP or low RUP) and GM $j(j=$ high or low ABV for milk fat + protein) at the $k$ th time ( $k=$ week 1 to 10 of lactation) for cow number $l(l=1$ to 82$) ; \mu=$ overall mean; $\beta_{i}=$ fixed effect of diet; $\gamma_{j}=$ fixed effect of GM; $\theta_{k}$ $=$ fixed effect of week (time); $(\beta \gamma)_{i j}=$ effect of diet by GM interaction; $(\beta \gamma \theta)_{i j k}=$ effect of diet by GM by week interaction; $X_{l}=$ random effect of animal; $\varepsilon_{i j k l}=$ random residual error within animal $l$, on diet $i$, with GM $j$ at week $k$. Indicator variables were included in models containing diet, GM, and week of lactation as a priori fixed effects. An autoregressive (AR1) covariance structure was used based on superior fit to other covariance structures. Variables that had a univariable $P$-value of less than 0.2 were included for evaluation in multivariable models using stepwise modeling with backward elimination. Once removed, variables were not eligible for re-entry into the model. Final models were 
Table 2. Descriptive analysis of BW, BCS, and predictor variables [mean (SD) averaged for the 3 wk before calving] ${ }^{1}$

\begin{tabular}{|c|c|c|c|c|}
\hline Variable & \multicolumn{2}{|c|}{ Diet } & \multicolumn{2}{|c|}{ Genetic merit } \\
\hline BW (kg) & $665.73(74.06)$ & $655.41(65.73)$ & $650.65(68.65)$ & $669.77(70.21)$ \\
\hline MP balance $(\mathrm{g} / \mathrm{d})$ & $511.38(183.34)$ & $356.18(128.14)$ & $444.83(168.89)$ & $426.95(183.58)$ \\
\hline ME balance (MJ of ME/d) & $27.44(33.34)$ & $57.14(30.85)$ & $44.99(23.77)$ & $39.00(43.52)$ \\
\hline Free fatty acids $(\mu \mathrm{mol} / \mathrm{L})$ & $264.57(149.63)$ & $298.95(243.40)$ & $258.90(145.37)$ & $305.33(246.76)$ \\
\hline Glucose (mmol/L) & $3.63(0.52)$ & $3.62(0.40)$ & $3.71(0.43)$ & $3.55(0.49)$ \\
\hline Calcium (mmol/L) & $2.29(0.27)$ & $2.26(0.25)$ & $2.30(0.26)$ & $2.24(0.25)$ \\
\hline Cholesterol (mmol/L) & $2.58(0.81)$ & $2.50(0.58)$ & $2.58(0.67)$ & $2.50(0.73)$ \\
\hline $\mathrm{BHB}(\mathrm{mmol} / \mathrm{L})$ & $1.82(1.51)$ & $1.34(0.36)$ & $1.36(0.31)$ & $1.30(0.31)$ \\
\hline
\end{tabular}

${ }^{1} \mathrm{ABV}=$ Australian Breeding Value for milk fat + protein yield.

assessed based on Wald tests and Akaike's information criterion (AIC) to evaluate model fit and confounding was assessed by evaluating changes in coefficients as new terms were added into the models. A similar mixed model with an independent covariance structure (XTMIXED, Stata version 13.1) was used to explore the significance of the precalving indicator variables on 8 factors of milk $\mathrm{CN}$ variant composition and yield (yield and percentage for each of $\alpha_{-}, \beta_{-}, \gamma_{-}$, and $\kappa_{-} \mathrm{CN}$ ). Multivariable models were determined in the same way as for milk yield and protein variables.

Reproductive Outcomes. The proportion of first services that resulted in pregnancy was assessed using logistic regression models (LOGISTIC, Stata version 13.1) with diet and GM included as a priori fixed effects. Indicator variables and early lactation production factors were included as individual covariables. Early lactation production factors included milk yield and protein and $\mathrm{CN}$ yield and percentage, and an average of the first $3 \mathrm{wk}$ of lactation was used. Those with $P$ values $<0.2$ were evaluated in multivariable backward stepwise modeling. A logistic normal nonparametric accelerated time failure survival analysis (STREG, Stata version 13.1) was used to further explore the effect of these precalving indicator variables and early lactation production factors on the risk of pregnancy up to 150 DIM. Cows that were not pregnant at 150 DIM were considered nonpregnant, even if they became pregnant after 150 DIM, resulting in right censoring of the data. Cows were then separated into quartiles based on their milk protein percentage (average of first 3 wk after calving) using the lowest quartile as reference group. A further analysis was then performed to assess the following time-varying covariables using a Cox's proportional hazards regression model (STCOX, Stata version 13.1) for calving to pregnancy interval: ME balance, MP balance, milk yield, milk protein per- centage, milk protein yield, CN percentage, CN yield, serum free fatty acids, and plasma urea, AAN, glucose, calcium, cholesterol, and BHB.

Milk Protein Percentage. Cows were again separated into quartiles based on their milk protein percentage, and cows with the lowest milk protein percentage were compared with those of the upper 3 quartiles using canonical linear discriminant analysis (CANDISC, Stata version 13.1). Significant differences that existed between the 2 groups in the precalving indicator variables and early lactation production traits were identified. A backward stepwise logistic regression (LOGISTIC, Stata version 13.1) was also performed to assess the results of the discriminant analysis and validated that these variables did differ (data not shown) between the groups with the lowest and higher milk protein content.

\section{RESULTS}

\section{Effect of Dietary Protein Degradability and GM on Indicator Variables}

Descriptive analyses of the average blood concentrations of indicator variables in the 3 wk prepartum are included in Table 2. Cows receiving more RUP in the diet or those of higher GM had numerically higher BW and lower BCS. An increased proportion of RUP in the diet increased prepartum MP balance (Table 3 and Figure 1), and cows of high GM tended to have a lower prepartum MP balance (Table 3 ). Figure 1 shows that this pattern continued into early lactation.

\section{Production Responses}

Univariable and multivariable relationships between indicator and production variables, in which diet, GM, 
Table 3. Effects of diet and genetic merit (GM) on MP balance; model includes effects of diet, GM, and diet $\times$ GM interaction ${ }^{1}$

\begin{tabular}{lccc}
\hline Evaluation & $\begin{array}{c}\text { Predicted mean } \\
(\mathrm{SE})(\mathrm{g} / \mathrm{d})\end{array}$ & $95 \% \mathrm{CI}$ & $\begin{array}{c}\text { Significance } \\
(P \text {-value })\end{array}$ \\
\hline Diet & $87.59(24.08)$ & $40.40-134.78$ & 0.001 \\
Low RUP & $405.77(23.50)$ & $359.72-451.82$ & \\
High RUP & & & 0.096 \\
Genetic merit & $223.15(23.50)$ & $177.10-269.20$ & \\
High ABV & $279.34(24.08)$ & $232.15-326.53$ & 0.794 \\
Low $\mathrm{ABV}^{2}$ & & & \\
Diet $\times \mathrm{GM}^{3}$ & &
\end{tabular}

${ }^{1}$ Week $P=0.0001$; diet $\times$ GM $\times$ week $P=0.6295$.

${ }^{2} \mathrm{ABV}=$ Australian Breeding Value for milk fat + protein yield.

${ }^{3}$ Predicted means for each of the 4 diet $\times$ GM interactions did not differ significantly and are not shown.

and week were included as a priori factors, are provided in Supplementary Table S2 (http://dx.doi.org/10.3168/ jds.2015-10275) and Table 4, respectively.

Milk Protein Yield and Percentage. The increase in milk protein production with the higher RUP diet was marked $(0.13 \mathrm{~kg} / \mathrm{cow}$ per day) (Table 4). Milk protein yield increased by approximately $0.08 \mathrm{~kg} / \mathrm{cow}$ per day in the group with higher GM for milk solids production (Table 4). Protein yield was associated with higher precalving plasma AAN concentrations, BW, and MP balance (Table 4, Supplementary Table S2; http://dx.doi.org/10.3168/jds.2015-10275). Milk protein percentage was unaffected by diet or GM (Table 4). Increased prepartum blood cholesterol, BW, and plasma AAN were associated with lower milk protein percentage (Table 4, Supplementary Table S2).

Milk Casein Yield and Percentage. Decreasing the degradability of the protein in the diet increased milk CN yield by $0.09 \mathrm{~kg} / \mathrm{d}$ (Table 4 , Figure 2). Body weight, MP balance, glucose, and disease all had significant associations with $\mathrm{CN}$ yield (Supplementary Table S2; http://dx.doi.org/10.3168/jds.2015-10275). Higher

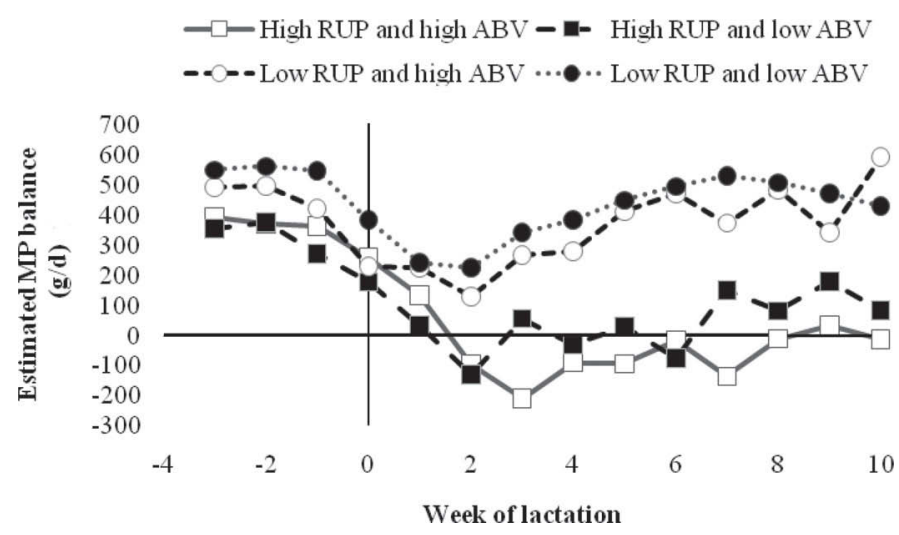

Figure 1. Effect of diet and genetic merit on estimated MP balance. $\mathrm{ABV}=$ Australian Breeding Value for milk fat + protein yield.
CN yield was observed in cows with higher precalving BW, consistent with the positive influence of BW on total milk protein yield. Incidence of severe disease lowered CN yield, when it was included in the model with BW. Increased prepartum plasma glucose concentrations were associated with lower $\mathrm{CN}$ concentrations, as was disease and plasma calcium and cholesterol when explored individually (Supplementary Table S2), but these latter 3 factors were confounded by glucose concentrations and became nonsignificant in multivariable models containing plasma glucose (Table 4). Milk $\mathrm{CN}$ concentration was consequently lower with higher glucose, BW, and AAN (Table 4). Diet and GM did not influence milk CN percentage (Table 4, Figure 3).

Casein Variant Yields and Percentages. Yields $(\mathrm{kg} / \mathrm{d})$ for $\mathrm{CN}$ variants were 0.49 and 0.45 of $\alpha-\mathrm{CN}$, 0.38 and 0.34 of $\beta-\mathrm{CN}$, and 0.07 and 0.06 of $\kappa-\mathrm{CN}$, for high- and low-RUP diets, respectively. $\gamma$-Casein had yields of 0.10 and 0.09 for high- and low-RUP diets, respectively. Reducing the degradability of protein in the diet increased yields of $\alpha-$ and $\beta-\mathrm{CN}$, but it did not significantly influence concentrations of any $\mathrm{CN}$ variants (Table 4). Largely consistent associations were found in the models evaluating the effects of individual indicator variables on $\mathrm{CN}$ variant yields and concentrations, with higher BW and AAN resulting in higher yield, but lower concentrations; decreased protein yield was associated with disease, and an increase in cholesterol was associated with decreased CN concentration. $\alpha$-Casein and $\beta$-CN yields were affected by the same variables as $\mathrm{CN}$ yield; increased by $\mathrm{BW}$ and decreased by disease (Table 4). Increased BW lowered $\alpha$ - and $\beta-\mathrm{CN}$ percentage but increased $\kappa$-CN yield. Increased $\mathrm{BCS}$ increased only $\gamma-\mathrm{CN}$ yield. Increased cholesterol concentrations were associated with lowered $\alpha_{-}, \gamma_{-}$, and $\kappa-\mathrm{CN}$ percentages, and higher precalving plasma calcium concentrations lowered $\kappa$-CN yield. Increased AAN concentrations precalving increased $\kappa-\mathrm{CN}$ yield and decreased $\alpha$ - and $\beta$-CN percentages. 
RODNEY ET AL.

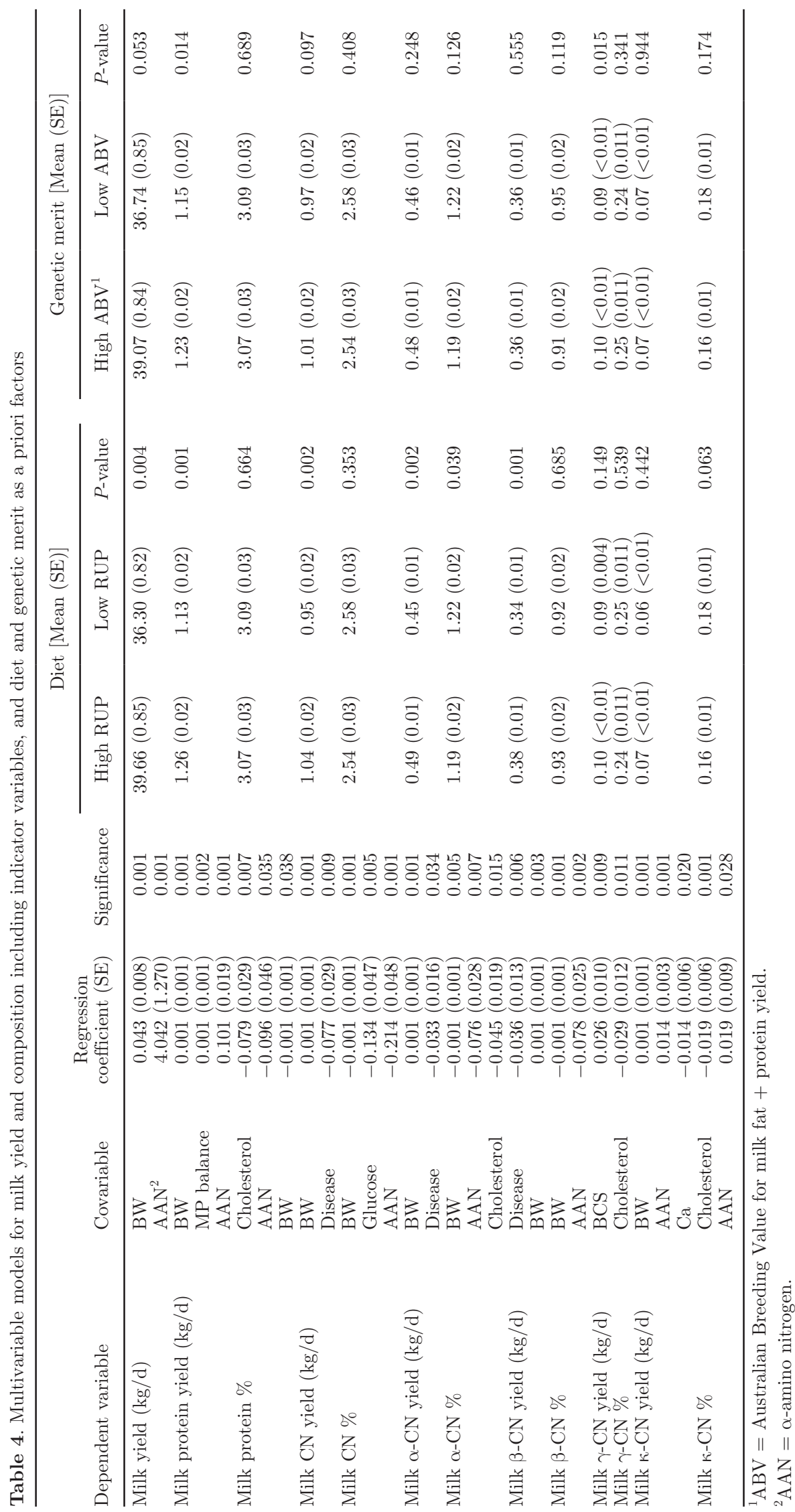


Table 5. Summary of reproductive variables; mean (no of cows) for pregnancy to first service, mean (SD) for interval from calving to pregnancy

\begin{tabular}{|c|c|c|c|c|}
\hline Reproductive variable $^{1}$ & \multicolumn{2}{|c|}{ Diet } & \multicolumn{2}{|c|}{ Genetic merit $^{2}$} \\
\hline $\begin{array}{l}\text { Pregnancy to first service }(\%) \\
\text { Interval from calving to pregnancy (d) }\end{array}$ & $\begin{array}{l}58(23 / 40) \\
94.75(32.47)\end{array}$ & $\begin{array}{c}41(17 / 41) \\
104.05(36.28)\end{array}$ & $\begin{array}{c}46(18 / 39) \\
102.90(5.33)\end{array}$ & $\begin{array}{l}52(22 / 42) \\
96.26(33.92)\end{array}$ \\
\hline
\end{tabular}

${ }^{1}$ Cows that were not pregnant at 150 DIM were considered nonpregnant, even if they became pregnant after 150 DIM, resulting in right censoring of the data.

${ }^{2} \mathrm{ABV}=$ Australian Breeding Value for milk fat + protein yield.

\section{Reproductive Responses}

Increasing the percentage of RUP in the diet increased the percentage of pregnancies to first service from 41 to $58 \%$ and tended to decrease the calving to pregnancy interval by $9 \mathrm{~d}$ (Table 5), although diet and GM were not significant when assessed in the multivariable model (Table 6). In the multivariable model, higher early lactation $\mathrm{CN}$ percentage and milk protein yield $(\mathrm{kg} / \mathrm{d})$ and decreased prepartum MP balance $(\mathrm{g} / \mathrm{d})$ improved the proportion of first services that resulted in pregnancy when diet, GM, and their interaction were included in the statistical model (Table 6). Individually, improved CN yield tended to be associated with increased pregnancy to first service (Supplementary Table S3; http://dx.doi.org/10.3168/jds.2015-10275), a result consistent with the positive effect of the higher RUP diet on CN yield and pregnancy to first service. None of the other factors tested univariably or as timevarying covariables influenced calving to pregnancy interval (data not shown).

\section{Low Milk Protein and CN}

To explore the hypothesis that low milk protein can predict poor fertility, cows were divided into quartiles and the group producing the lowest milk protein percentage was compared with the cows in the upper 3 quartiles. The hazard of pregnancy was $28 \%$ lower in cows producing the lowest quartile of milk protein percentage during the first 150 DIM compared with the upper 3 quartiles (Table 7, Figure 4). Differences in the precalving indicator variables between the 2 groups were explored using discriminant analysis and logistic regression. Both methods identified the same factors associated with lowest milk protein percentage (Table 8). Cows producing a lower milk protein percentage produced $3.87 \mathrm{~L} /$ cow per day more milk on average than cows in the other 3 quartiles (Table 9). They also had higher prepartum plasma calcium and glucose and estimated MP balance compared with the group producing a higher milk protein percentage (Tables 7 and 8). The group with low milk protein had $0.17 \mathrm{mmol} / \mathrm{L}$ less urea in the blood prepartum on average than the group producing a higher milk protein percentage.

\section{DISCUSSION}

This study re-examines and builds on the original work of Garvin (1999), Westwood (1998), and Westwood et al. (2000, 2002), using the milk composition data set of the first study and the reproductive data sets of the latter two. The detail and high quality of these data provided the opportunity to explore new hypotheses and improve metabolic understanding of milk protein and $\mathrm{CN}$ variants. This study had 3 main aims: (1) to describe the effects of protein nutrition and GM on CN variants; (2) to explore precalving and early lactation factors that may predict production, especially protein and $\mathrm{CN}$ production, and reproductive performance, and (3) to evaluate an a priori hypothesis that low milk protein content is associated with poor fertility and to

Table 6. Logistic regression model of factors affecting the proportion of first services that resulted in pregnancy

\begin{tabular}{|c|c|c|c|}
\hline Variable & Odds ratio (SE) & $95 \% \mathrm{CI}$ & $\begin{array}{l}\text { Significance } \\
(P \text {-value })\end{array}$ \\
\hline$\overline{\text { Diet }^{1}}$ & $0.86(0.622)$ & $0.210-3.545$ & 0.839 \\
\hline Genetic merit $(\mathrm{GM})^{2}$ & $0.86(0.603)$ & $0.217-3.401$ & 0.828 \\
\hline Diet $\times$ genetic merit & $1.10(1.090)$ & $0.156-7.697$ & 0.926 \\
\hline $\mathrm{CN} \%$ & $9.86(10.261)$ & $1.283-75.782$ & 0.028 \\
\hline Milk protein yield $(\mathrm{kg} / \mathrm{d})$ & $20.09(27.721)$ & $1.344-300.264$ & 0.030 \\
\hline MP balance (g/d) & $1.00(0.002)$ & $0.993-0.999$ & 0.044 \\
\hline
\end{tabular}




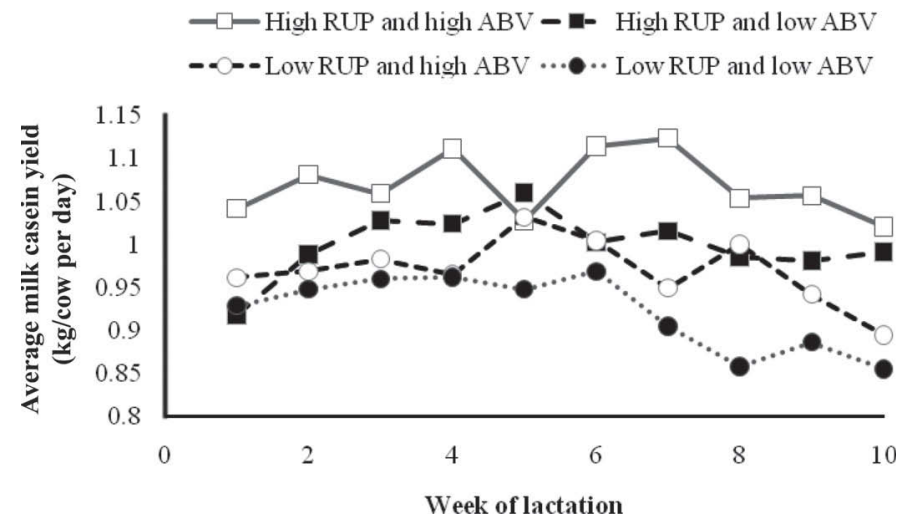

Figure 2. Average milk casein yield by week for diet and genetic merit groups. ABV = Australian Breeding Value for milk fat + protein yield.

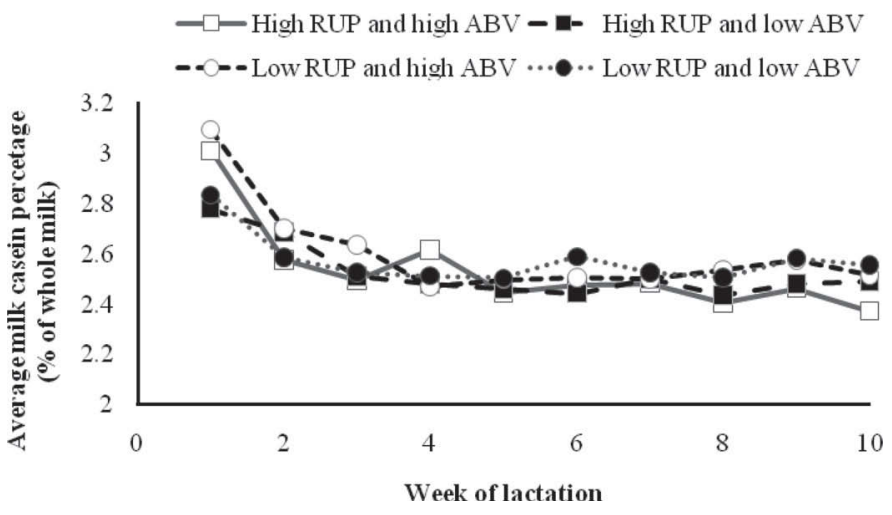

Figure 3. Average milk casein percentage by week for diet and genetic merit groups. ABV = Australian Breeding Value for milk fat + protein yield.

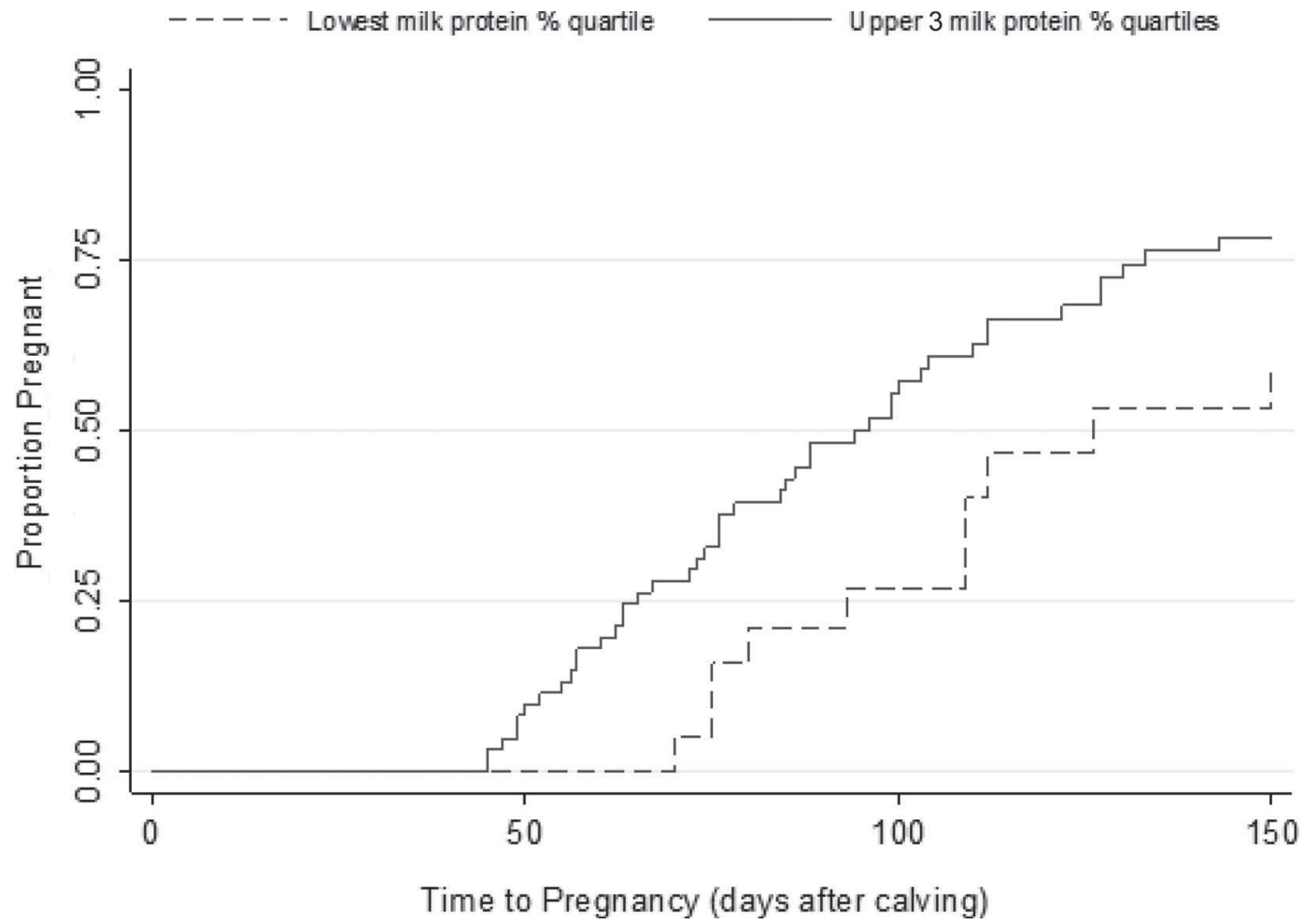

Figure 4. Kaplan-Meier survival plot of the time to pregnancy within 150 d, separated for cows producing the lowest quartile of milk protein percentage and the upper 3 quartiles of milk protein percentage.

Table 7. Multivariable model of factors predicting time to pregnancy within $150 \mathrm{~d}$ of calving using a logistic normal nonparametric accelerated time failure survival analysis, with milk protein percentage as a binary variable (lowest quartile as reference group)

\begin{tabular}{lccc}
\hline Variable & $\begin{array}{c}\text { Hazard ratio } \\
(\mathrm{SE})\end{array}$ & $\begin{array}{c}95 \% \text { CI for hazard } \\
\text { ratio }\end{array}$ & $\begin{array}{c}\text { Significance } \\
(P \text {-value })\end{array}$ \\
\hline Diet $^{1}$ & $1.05(0.115)$ & $0.850-1.303$ & 0.640 \\
Genetic merit $^{2}$ & $1.01(0.110)$ & $0.812-1.245$ & 0.962 \\
Milk protein \% & $0.72(0.096)$ & $0.556-0.936$ & 0.014 \\
\hline
\end{tabular}

${ }^{1}$ The diet higher in RUP was used as the reference group.

${ }^{2}$ Genetic merit is defined as Australian Breeding Value (ABV) for milk fat + protein yield. The higher ABV was used as the reference group. 
Table 8. Multivariable model for factors affecting low milk protein percentage, created using backward stepwise logistic regression

\begin{tabular}{lccc}
\hline Variable & Odds ratio & $95 \% \mathrm{CI}$ & $\begin{array}{c}\text { Significance } \\
(P \text {-value })\end{array}$ \\
\hline Average milk yield $(\mathrm{kg} / \mathrm{d})$ & $0.91(0.041)$ & $0.831-0.993$ & 0.034 \\
Average urea (mmol/L) & $1.97(0.624)$ & $1.063-3.666$ & 0.031 \\
Average glucose (mmol/L) & $0.24(0.170)$ & $0.058-0.971$ & 0.045 \\
Average calcium (mmol/L) & $0.04(0.055)$ & $0.002-0.653$ & 0.024 \\
Average MP balance (g/d) & $1.00(0.002)$ & $0.992-1.000$ & 0.029 \\
\hline
\end{tabular}

understand the factors, including $\mathrm{CN}$ variant yield and composition, that contribute to this situation. Factors after calving and around breeding that can be used as predictors of fertility and production were well explored by Westwood et al. (2000, 2002). This study explores factors before calving and in very early lactation that influence fertility and production. Because of the large amount of analyses, we have not sought to address all of these factors in the Discussion but have focused on the most important results, which are summarized in the conclusion, and on consistently identified metabolic influences on production and reproduction in the study.

Individual CN composition may affect milk-processing outcomes; however, little information exists on yields of CN variants (Barry and Donnelly, 1980; Kroeker et al., 1985; Davies and Law, 1987) or nutritional and metabolic factors that may determine individual CN yields or percentages. Average $\mathrm{CN}$ content varied considerably between individual cows (range 1.3-4.5\% total milk, average $2.6 \%$ ) (Garvin, 1999). In this study, $\alpha-, \beta-, \kappa_{-}^{-}$, and $\gamma-\mathrm{CN}$ represented approximately $47,37,7$, and $9 \%$ of total CN, respectively (Garvin, 1999). $\alpha$-Casein concentrations were similar to those presented by Davies and Law (1980), Barry and Donnelly (1980), and Kroeker et al. (1985) (48.3, 48.7, and 59.9\%, respectively). The $\beta$-CN percentage was similar to that of Davies and Law (1980) and Barry and Donnelly (1980) (35.7 and $33.8 \%$, respectively), although $\kappa-\mathrm{CN}$ was lower and $\gamma-\mathrm{CN}$ was higher than previously reported (12.8 and $3.2 \%$ for $\kappa$ - and $\gamma-\mathrm{CN}$, respectively) (Davies and Law, 1980). Different milk protein polymorphisms may also be associated with changes in milk, milk fat, and milk protein yields (Ng-Kwai-Hang et al., 1984), but these were not explored in this study. It is unsurprising that the factors affecting $\alpha$ - and $\beta$-CN yields were the same those identified for total CN yield because these collectively accounted for more than $80 \%$ of total CN yield.

Milk yield and milk protein responses to changes in dietary protein and AA supply are variable (Doepel et al., 2004). In this study, increasing the ratio of RUP:RDP in the diet by using a high-quality protein source increased early lactation milk, milk protein, and milk CN yield. The milk yield response is similar to linear increases in production in response to increased RUP supplementation (Wright et al., 1998). However, in a review of 127 trials that replaced soybean meal with sources higher in RUP, only $17 \%$ of comparisons identified significantly higher milk yield in groups fed higher RUP (Santos et al., 1998). This effect varied, based on the type of RUP source used, possibly because of changes in profile of absorbed AA. Sannes et al. (2002) did not find an effect on milk yield of feeding increased RDP, nor did Reynal and Broderick (2005). These varying responses reflect the complexity of assessing and improving MP status and a limitation in study design of nutritional studies, in which the substitution of one feed for another creates a complex series of changes that may not simply increase the MP supply of the most rate-limiting AA nor improve the overall nutrient balance. Importantly, in the current study, lower protein degradability significantly increased estimated MP balance (Table 3) and increased milk, protein, and $\mathrm{CN}$ yields, all indicating a positive effect of the diet higher in RUP (Tables 2 and 4). Further, milk $\alpha_{-}^{-}, \beta-$, and $\gamma$-CN yields were significantly increased by feeding the diet higher in RUP (Tables 2 and 4), with only the percentage of $\alpha-\mathrm{CN}$ declining significantly with diet or GM. In general, increased yield of milk proteins is as-

Table 9. Group means (SD) of indicator variables differing between cows of lowest quartile for milk protein percentage or in the 3 higher quartiles identified using canonical linear discriminant analysis

\begin{tabular}{lcc}
\hline Variable & Low milk protein & Average-high milk protein \\
\hline Average milk yield (L/d) & $40.70(6.901)$ & $36.83(6.844)$ \\
Average urea (mmol/L) & $5.64(1.247)$ & $5.81(1.302)$ \\
Average glucose (mmol/L) & $3.77(0.380)$ & $3.57(0.486)$ \\
Average calcium (mmol/L) & $2.37(0.295)$ & $2.24(0.235)$ \\
Average MP balance (g/d) & $497.38(174.013)$ & $414.43(175.375)$ \\
\hline
\end{tabular}


sociated with lower concentrations, often as a result of increased milk production.

The tendency for increased early lactation milk yield for cows with higher ABV (Table 4) has been identified in other studies (Flux et al., 1984). Increased prepartum MP balance increased milk protein yield (Table 4). Cows in both dietary groups had excellent weight gain before calving, suggesting that neither group was limited by ME or MP availability prepartum (Table 2 ). The cows with higher ABV tended to have lower prepartum estimated ME and MP balances (Westwood et al., 2000; Tables 2 and 4). Abundant literature examines the detrimental effects of a negative energy balance on fertility (Wathes et al., 2007). However, in this study, ME balance before calving did not contribute to any production or fertility model (Table 4). Milk production and DMI are key determinants of ME and MP balances, and based on the current results, the importance of MP balance should be given further consideration in fertility studies.

Further insight into the factors present before calving that influence production traits, is provided in Table 4 and Supplementary Table S2 (http://dx.doi. org/10.3168/jds.2015-10275). Prepartum BW and AAN increased production for most production variables studied (Table 4, Supplementary Table S2). Body weight reflects the endogenous nutrient reserves available to the cow, and it is unsurprising that this factor increased milk, protein, $\mathrm{CN}, \alpha-\mathrm{CN}, \beta-\mathrm{CN}$, and $\kappa-\mathrm{CN}$ yields because it reflects an improved energy and nutrient status of cows. However, percentages of CN and $\beta-\mathrm{CN}$ were lower with higher BW precalving. Free circulating AA, as indicated by a higher AAN concentration, are the main precursors for milk protein and perhaps reflect labile protein stores and were associated with higher milk, protein, and $\kappa$-CN yields. Again lower milk CN concentration, including $\alpha-$ and $\beta-\mathrm{CN}$, and consequently lowered milk protein percentage were associated with higher prepartum AAN (Table 4). The lower percentages of proteins may possibly have resulted from the positive effect of BW and AAN on milk yield. A negative effect of cholesterol on milk protein and $\alpha-$, $\gamma$, and $\kappa$-CN percentages (Table 4) was unexpected, and a causal link is not immediately obvious. However, increased cholesterol reflects a more positive energy balance (Lean et al., 1992) and may indicate a more anabolic state in which milk production is increased, decreasing milk protein and CN content. Therefore, the association of cholesterol itself with milk protein and CN content may not be causal but reflect this relationship with yield. Higher blood glucose, calcium, and cholesterol concentrations were associated with lower CN concentration, but glucose statistically confounded the other variables, which became nonsignificant in multivariable models. Prepartum plasma calcium was a significant factor in several models (Supplementary Table S2; http://dx.doi.org/10.3168/jds.2015-10275), but it only increased $\kappa-\mathrm{CN}$ yield in the multivariable model. This finding may reflect the metabolic interactions between calcium and other indicator variables. For example, bone calcium and glucose are causally linked through osteocalcin and insulin metabolism, as was shown in murine studies (Lee et al., 2007), and reviewed in a bovine context (Lean et al., 2014). Elegant intervention studies by Martinez et al. (2014) demonstrated the central role of hypocalcaemia in influencing insulin and glucose concentrations. Further work is required to confirm the importance of these observations, but they suggest that relationships among bone and energy metabolism may be reflected in production and reproductive outcomes.

Westwood et al. (2002) identified a positive effect of increased RUP intake on fertility. However, in a multivariable model containing diet, GM, diet $\times$ GM interaction, CN percentage, and milk protein yield, higher prepartum MP balance lowered the risk of pregnancy to first service (Table 6). Other factors in this model, namely, CN percentage and milk protein yield, increased the proportion pregnant to first service, suggesting that cows receiving a diet higher in RUP that resulted in higher milk CN percentage were less successful reproductively if they retained more MP precalving or were less efficient with MP utilization. On average, cows in both dietary groups had substantial positive MP balances before calving. These findings, in conjunction with the results in Table 4 and Supplementary Table S2 (http://dx.doi.org/10.3168/jds.2015-10275), suggest the possibility that the reproductive response to anabolic stimuli precalving, such as BW, MP balance, and AAN that produced more milk, protein, and $\mathrm{CN}$ yields, may be curvilinear. Diets after calving may not be able to provide the protein, energy, fats, and other nutrients required to produce the extra proteins, fat, lactose, and other components of increased milk production stimulated by improved protein status prepartum.

Support for this concept comes from the observation that cows in the lowest quartile of milk protein percentage had slower times to pregnancy within $150 \mathrm{~d}$ of calving compared with cows in the other 3 quartiles. Further, a numerically lower proportion of the cows in this group were pregnant by 150 DIM (Table 7, Figure 4). Cows with higher milk CN percentage had greater odds of pregnancy to first service (Table 6). The multivariable model that described the linear milk protein percentage response (Table 4) differs from the factors that were associated with the lowest milk protein percentage quartile group (Table 9); however, considerable consistency is present because both models indicate 
that factors that reflect an increased stimulus to milk reduced milk protein percentage. Further, the cows in these groups differed between the analyses because the latter compared 1 quartile of cows with the other 3 . Cows in the lowest protein group had higher milk yield on average than those producing milk of a higher protein percentage. Plasma calcium and glucose and estimated MP balance were all higher before calving in the group producing low milk protein percentage. The latter measures reflect anabolic processes and support the observation that these cows had increased early lactation milk yield. The lowest milk protein group would therefore have had a greater irreversible loss of nutrients in milk, particularly thorough increased lactose production, and possibly an increase in protein and glucose used for mammogenesis in the early lactation period. Bickerstaffe et al. (1974) estimated that 69 to $98 \%$ of circulating glucose was used by the mammary gland. Most of this glucose is used as a precursor for lactose synthesis, but it is also essential as the main source of energy for the mammary gland (Wood et al., 1965) and ovary (Rabiee et al., 1997). Consequently, low milk protein and $\mathrm{CN}$ content may reflect disordered metabolic control in cows stimulated to produce more lactose and protein. Indicator variables before calving and a diet higher in RUP that had positive effects on reproduction and production reflected anabolic processes; however, it appears that not all cows are capable of integrating the nutrient demands for lactation with those required for reproductive outcomes. This population may be identified through a low milk protein or $\mathrm{CN}$ concentration.

\section{CONCLUSIONS}

The objectives of this study were (1) to describe the effects of protein nutrition and GM on CN variants; (2) to explore precalving and early lactation factors that may predict production, especially protein and CN production, and reproductive performance; and (3) to evaluate an a priori hypothesis that low milk protein content is associated with poor fertility and to understand the factors, including $\mathrm{CN}$ variant yield and composition, that contribute to this situation. We were able to conclude that decreasing protein degradability in the diet increased milk, milk protein, and CN yields, and increased GM increased milk protein and $\gamma$-CN yields and tended to increase milk $\mathrm{CN}$ yield. We also found that the effects of indicator variables that may predict productive and reproductive outcomes were largely consistent, confirming the importance of some well-determined causal factors such as BW and disease and identifying some less well-explored indicators, including cholesterol and AAN that are worthy of further exploration. A diet high in RUP increased the proportion of first services that resulted in pregnancy, suggesting a positive effect of increased MP on fertility. However, when combined in a model containing CN yield, diet, GM, and diet $\times$ GM interaction, higher prepartum MP balance lowered the risk of pregnancy to first service. This finding suggests that the effects of increasing dietary RUP on fertility may be curvilinear. Anabolic factors measured prepartum, including BW, AAN, cholesterol, and glucose, increase production of milk, protein, $\mathrm{CN}$, and $\mathrm{CN}$ variants, but they tended to reduce the percentage of these components in milk. Finally, we found low milk protein percentage in early lactation was associated with a lower risk of pregnancy within 150 DIM and a low milk CN percentage was associated with a lower proportion of cows pregnant at first service. Early lactation milk yield and prepartum MP balance and glucose and calcium concentrations were higher in the cows producing lower milk protein percentage, and prepartum urea was higher in this group. Metabolizable protein balance was significant and important to both production and reproduction, but surprisingly, ME balance was not. This study demonstrates the importance of protein metabolism to productive and reproductive performance.

\section{ACKNOWLEDGMENTS}

This study was supported by Dairy Australia (Project Number: C100000540; Melbourne, Victoria, Australia) and Scibus (Camden, New South Wales, Australia). The original data were collected as the result of a Collaborative Research Grant, partners who are recognized in Westwood et al. (2000). Appreciation is also extended to H. Lyons and A. Lean (Scibus, Camden, New South Wales, Australia) for their assistance with data modelling.

\section{REFERENCES}

Agricultural and Food Research Council (AFRC). 1993. Requirements for metabolisable energy. Pages 21-32 in Energy and Protein Requirements of Ruminants. CAB International, Wallingford, UK.

Barry, J. G., and W. J. Donnelly. 1980. Casein compositional studies: 1. The composition of casein from Friesian herd milks. J. Dairy Res. 47:71-81.

Bell, A. W. 1995. Regulation of organic nutrient metabolism during transition from late pregnancy to early lactation. J. Anim. Sci. 73:2804-2819.

Bickerstaffe, R., E. Annison, and J. Linzell. 1974. The metabolism of glucose, acetate, lipids and amino acids in lactating dairy cows. J. Agric. Sci. 82:71-85.

Bradford, B. J., K. Yuan, J. K. Farney, L. K. Mamedova, and A. J. Carpenter. 2015. Invited review: Inflammation during the transition to lactation: New adventures with an old flame. J. Dairy Sci. 9866316650

Buckley, F., P. Dillon, M. Rath, and R. Veerkamp. 2000. The relationship between genetic merit for yield and live weight, condition score, and energy balance of spring calving Holstein Friesian dairy 
cows on grass based systems of milk production. J. Dairy Sci. 83:1878-1886.

Buckley, F., K. O'Sullivan, J. Mee, R. Evans, and P. Dillon. 2003. Relationships among milk yield, body condition, cow weight, and reproduction in spring-calved Holstein-Friesians. J. Dairy Sci. 86:2308-2319.

Butler, W. R. 2000. Nutritional interactions with reproductive performance in dairy cattle. Anim. Reprod. Sci. 60-61:449-457.

Carroll, D. J., F. R. Hossain, and M. R. Keller. 1994. Effect of supplemental fish meal on the lactation and reproductive performance of dairy cows. J. Dairy Sci. 77:3058-3072.

Chapinal, N., M. Carson, S. LeBlanc, K. Leslie, S. Godden, M. Capel, J. Santos, M. Overton, and T. Duffield. 2012. The association of serum metabolites in the transition period with milk production and early-lactation reproductive performance. J. Dairy Sci. 95:1301-1309.

Coulon, J.-B., C. Hurtaud, B. Remond, and R. Verite. 1998. Factors contributing to variation in the proportion of casein in cows' milk true protein: A review of recent INRA experiments. J. Dairy Res. 65:375-387.

Cunningham, K. D., M. J. Cecava, T. R. Johnson, and P. A. Ludden 1996. Influence of source and amount of dietary protein on milk yield by cows in early lactation. J. Dairy Sci. 79:620-630.

Davies, D. T., and A. J. Law. 1980. The content and composition of protein in creamery milks in south-west Scotland. J. Dairy Res. $47: 83-90$

Davies, D. T., and A. J. Law. 1987. Quantitative fractionation of casein mixtures by fast protein liquid chromatography. J. Dairy Res. 54:369-376.

Doepel, L., D. Pacheco, J. Kennelly, M. Hanigan, I. López, and H. Lapierre. 2004. Milk protein synthesis as a function of amino acid supply. J. Dairy Sci. 87:1279-1297.

Edmondson, A., I. Lean, L. Weaver, T. Farver, and G. Webster. 1989. A body condition scoring chart for Holstein dairy cows. J. Dairy Sci. 72:68-78.

Flux, D., D. Mackenzie, and G. Wilson. 1984. Plasma metabolite and hormone concentrations in friesian cows of differing genetic merit measured at two feeding levels. Anim. Prod. 38:377-384.

Folman, Y., H. Neumark, M. Kaim, and W. Kaufmann. 1981. Performance, rumen and blood metabolites in high-yielding cows fed varying protein percents and protected soybean. J. Dairy Sci. 64:759-768.

Fox, P. F., and D. M. Mulvihill. 1982. Milk proteins: Molecular, colloidal and functional properties. J. Dairy Res. 49:679-693.

Garnsworthy, P., and J. Topps. 1982. The effect of body condition of dairy cows at calving on their food intake and performance when given complete diets. Anim. Prod. 35:113-119.

Garvin, J. 1999. The effect of dietary protein degradability and genetics on the protein quality of milk for cheese manufacture. PhD Dissertation. Faculty of Veterinary Science, University of Sydney, Australia.

Hageman, W. H., G. Shook, and W. Tyler. 1991. Reproductive performance in genetic lines selected for high or average milk yield. J. Dairy Sci. 74:4366-4376.

Horan, B., J. Mee, P. O'Connor, M. Rath, and P. Dillon. 2005. The effect of strain of Holstein-Friesian cow and feeding system on postpartum ovarian function, animal production and conception rate to first service. Theriogenology 63:950-971.

Kroeker, E., K. Ng-Kwai-Hang, J. Hayes, and J. Moxley. 1985. Effects of environmental factors and milk protein polymorphism on composition of casein fraction in bovine milk. J. Dairy Sci. 68:1752-1757.

Lean, I., P. DeGaris, L. Wade, and Z. Rajczyk. 2003. Transition management of dairy cattle. Pages 221-248 in Proc. of Australian and New Zealand Combined Dairy Veterinarians' Conf., Taupo, New Zealand.

Lean, I. J., T. B. Farver, H. F. Troutt, M. L. Bruss, J. C. Galland, R L. Baldwin, C. A. Holmberg, and L. D. Weaver. 1992. Time series cross-correlation analysis of postparturient relationships among serum metabolites and yield variables in Holstein cows. J. Dairy Sci. 75:1891-1900.
Lean, I. J., P. Celi, H. Raadsma, J. McNamara, and A. R. Rabiee. 2012. Effects of dietary crude protein on fertility: Meta-analysis and meta-regression. Anim. Feed Sci. Technol. 171:31-42.

Lean, I. J., P. J. DeGaris, P. Celi, D. M. McNeill, R. M. Rodney, and D. R. Fraser. 2014. Influencing the future: Interactions of skeleton, energy, protein and calcium during late gestation and early lactation. Anim. Prod. Sci. 54:1177-1189.

Lean, I. J., J. C. Galland, and J. L. Scott. 1989. Relationships between fertility, peak milk yields and lactational persistency in dairy cows. Theriogenology 31:1093-1103.

Lean, I. J., R. Van Saun, and P. J. DeGaris. 2013. Energy and protein nutrition management of transition dairy cows. Vet. Clin. North Am. Food Anim. Pract. 29:337-366.

LeBlanc, S. 2010. Monitoring metabolic health of dairy cattle in the transition period. J. Reprod. Dev. 56:S29-S35.

Lee, N. K., H. Sowa, E. Hinoi, M. Ferron, J. D. Ahn, C. Confavreux, R. Dacquin, P. J. Mee, M. D. McKee, and D. Y. Jung. 2007. Endocrine regulation of energy metabolism by the skeleton. Cell 130:456-469.

Leroy, J. L., A. Van Soom, G. Opsomer, I. G. Goovaerts, and P. V. Bols. 2008. Reduced fertility in high-yielding dairy cows: Are the oocyte and embryo in danger? Part II. Mechanisms linking nutrition and reduced oocyte and embryo quality in high-yielding dairy cows. Reprod. Domest. Anim. 43:623-632.

Leroy, J. L., T. Vanholder, B. Mateusen, A. Christophe, G. Opsomer, A. de Kruif, G. Genicot, and A. Van Soom. 2005. Non-esterified fatty acids in follicular fluid of dairy cows and their effect on developmental capacity of bovine oocytes in vitro. Reproduction 130:485-495.

López-Gatius, F., J. Yániz, and D. Madriles-Helm. 2003. Effects of body condition score and score change on the reproductive performance of dairy cows: A meta-analysis. Theriogenology 59:801-812.

Madouasse, A., J. Huxley, W. Browne, A. Bradley, I. Dryden, and M. Green. 2010. Use of individual cow milk recording data at the start of lactation to predict the calving to conception interval. J. Dairy Sci. 93:4677-4690.

Martinez, N., L. Sinedino, R. Bisinotto, E. Ribeiro, G. Gomes, F. Lima, L. Greco, C. Risco, K. Galvão, and D. Taylor-Rodriguez. 2014. Effect of induced subclinical hypocalcemia on physiological responses and neutrophil function in dairy cows. J. Dairy Sci. $97: 874-887$.

McCormick, M. E., D. D. French, T. F. Brown, G. J. Cuomo, A. M. Chapa, J. M. Fernandez, J. F. Beatty, and D. C. Blouin. 1999. Crude protein and rumen undegradable protein effects on reproduction and lactation performance of Holstein cows. J. Dairy Sci. 82:2697-2708

Morton, J. 2004. Determinants of reproductive performance of dairy cows in commercial herds in Australia. PhD Dissertation. Veterinary Science, University of Melbourne, Australia.

Moss, N. 2001. The epidemiology of subfertility in Australian dairy cows. PhD Dissertation. Faculty of Veterinary Science, University of Sydney, Australia.

Ng-Kwai-Hang, K. F., J. F. Hayes, J. E. Moxley, and H. G. Monardes. 1984. Association of genetic variants of casein and milk serum proteins with milk, fat, and protein production by dairy cattle. J. Dairy Sci. 67:835-840.

Ospina, P. A., D. V. Nydam, T. Stokol, and T. R. Overton. 2010. Associations of elevated nonesterified fatty acids and $\beta$-hydroxybutyrate concentrations with early lactation reproductive performance and milk production in transition dairy cattle in the northeastern United States. J. Dairy Sci. 93:1596-1603.

Patton, J., D. Kenny, S. McNamara, J. Mee, F. O'Mara, M. Diskin, and J. Murphy. 2007. Relationships among milk production, energy balance, plasma analytes, and reproduction in Holstein-Friesian cows. J. Dairy Sci. 90:649-658.

Pollott, G. E., and M. P. Coffey. 2008. The effect of genetic merit and production system on dairy cow fertility, measured using progesterone profiles and on-farm recording. J. Dairy Sci. 91:3649-3660.

Rabiee, A. R., I. J. Lean, J. M. Gooden, B. G. Miller, and R. J. Scaramuzzi. 1997. An evaluation of transovarian uptake of metabolites 
using arterio-venous difference methods in dairy cattle. Anim. Reprod. Sci. 48:9-25.

Reynal, S. M., and G. A. Broderick. 2005. Effect of dietary level of rumen-degraded protein on production and nitrogen metabolism in lactating dairy cows. J. Dairy Sci. 88:4045-4064.

Sannes, R. A., M. A. Messman, and D. B. Vagnoni. 2002. Form of rumen-degradable carbohydrate and nitrogen on microbial protein synthesis and protein efficiency of dairy cows. J. Dairy Sci. 85:900-908.

Santos, F. A., J. E. Santos, C. B. Theurer, and J. T. Huber. 1998. Effects of rumen-undegradable protein on dairy cow performance: A 12-year literature review. J. Dairy Sci. 81:3182-3213.

Spalding, R. W., R. W. Everett, and R. H. Foote. 1975. Fertility in New York artificially inseminated Holstein herds in Dairy Herd Improvement. J. Dairy Sci. 58:718-723.

van Saun, R. J., S. C. Idleman, and C. J. Sniffen. 1993. Effect of undegradable protein amount fed prepartum on postpartum production in first lactation Holstein cows. J. Dairy Sci. 76:236-244.

Wathes, D. C., M. Fenwick, Z. Cheng, N. Bourne, S. Llewellyn, D. G. Morris, D. Kenny, J. Murphy, and R. Fitzpatrick. 2007. Influence of negative energy balance on cyclicity and fertility in the high producing dairy cow. Theriogenology 68:S232-S241.

Westwood, C. 1998. Effects of dietary protein degradability and genetic merit on the reproductive performance of lactating dairy cows. PhD Thesis. Faculty of Veterinary Science, University of Sydney, Australia.

Westwood, C. T., I. J. Lean, and J. K. Garvin. 2002. Factors influencing fertility of Holstein dairy cows: A multivariate description. J. Dairy Sci. 85:3225-3237.

Westwood, C. T., I. J. Lean, J. K. Garvin, and P. C. Wynn. 2000. Effects of genetic merit and varying dietary protein degradability on lactating dairy cows. J. Dairy Sci. 83:2926-2940.

Wood, H. G., G. J. Peeters, R. Verbeke, M. Lauryssens, and B. Jacobson. 1965. Estimation of the pentose cycle in the perfused cow's udder. Biochem. J. 96:607-615.

Wright, T. C., S. Moscardini, P. H. Luimes, P. Susmel, and B. W. McBride. 1998. Effects of rumen-undegradable protein and feed intake on nitrogen balance and milk protein production in dairy cows. J. Dairy Sci. 81:784-793. 